Int. J. Dev. Biol. 53: 851-856 (2009)

doi: $10.1387 /$ ijdb.072502sk

\title{
How animals get their skin patterns: fish pigment pattern as a live Turing wave
}

\author{
SHIGERU KONDO*,1, MOTOKO IWASHITA² and MOTOOMI YAMAGUCHI ${ }^{3}$
}

\begin{abstract}
${ }^{1}$ Graduate School of Frontier Biosciences, Osaka University, Suita, Osaka, Japan, ${ }^{2}$ Unit on Neural Circuits and Adaptive Behaviors, Genes, Cognition and Psychosis Program, National Institute of Mental Health / NIH, Bethesda, MD, USA and ${ }^{3}$ Center of Developmental Biology, Riken, Chuo-ku, Japan
\end{abstract}

\begin{abstract}
It is more than fifty years since Alan Turing first presented the reaction-diffusion (RD) model, to account for the mechanism of biological pattern formation. In the paper entitled "The chemical basis of morphogenesis", Turing concluded that spatial patterns autonomously made in the embryo are generated as the stationary wave of the chemical (cellular) reactions. Although this novel idea was paid little attention by experimental biologists, recent experimental data are suggesting that the RD mechanism really functions in some of the course of animal development. Among the phenomena in which involvement of the RD mechanism is suspected, the striped pigment pattern of zebrafish has been highlighted as an ideal model system for the following reasons: the stationary wave made by the RD mechanism stays alive and can be observed only in the fish skin; and in zebrafish, we can utilize genomic information and molecular genetic techniques to clarify the molecular basis of pattern formation. In this review, we summarize recent progresses in the study of zebrafish pigment pattern formation that is uncovering how the RD wave is made and maintained in the skin.
\end{abstract}

KEY WORDS: pattern formation, reaction-diffusion system, zebrafish, pigment cell, Turing

\section{Mechanisms of biological pattern formation}

One of the major issues in developmental biology is how positional information is laid down in the tissues and bodies of animals. Research in molecular genetics during the past three decades has proved that eggs already possess a substantial degree of positional information as evidenced by the localized distribution of key molecules proteins or ribonucleic acids (RNAs). (Gilbert, 2003; Wolpert, 2006) Cells in an embryo are able to read their position from the concentration of such molecules, and are thereby induced to undergo position-specific differentiation. The differentiated cell can produce signaling molecules that are used as secondary positional information. By repeating this induction cascade, it is theoretically possible to determine positional information in later stages.(Wolpert, 1969; Wolpert, 1989) This simple mechanism, generally called "pre-pattern theory" or "morphogen theory," has been experimentally proved in many morphogenetic events in early development, and is widely accepted as a mecha- nistic principle that functions when spatial patterns are laid down in the embryos. However, this simple mechanism is apparently not fully capable of accounting for the complex structures of the adult body because its complexity far exceeds the positional information of the egg.

Moreover, many examples have shown that animal development is quite robust against the artificial disturbance of primary structures. For example, hydra can regenerate correct structures from an aggregate of dispersed cells.(Bode, 2003; Guder et al., 2006; Wolpert etal., 1971) When a planarian is cut into pieces, the complete structure is regenerated from each piece(Agata et al., 2007; Best and Morita, 1982), suggesting that there is no fixed origin of a "morphogen." This amazing robustness of animal development implies the existence of the second principle of spatial pattern formation, which is independent of the pre-existing

Abbreviations used in this paper: RD, reaction-diffusion; RNA, ribonucleic acid.

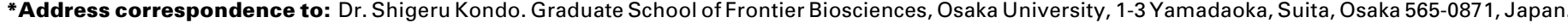
Fax: :+81-6-6879-7977.e-mail: shigerukondo@gmail.com or skondo@fbs.osaka-u.ac.jp
}

Published online: 18 June 2009.

ISSN: Online 1696-3547, Print 0214-6282

(c) 2009 UBC Press

Printed in Spain 
positional information that is established in the egg.

\section{RD mechanism: an autonomous mechanism that can generate the spatial pattern}

There are several theoretical mechanisms that are able to generate spatial patterns autonomously without any pre-pattern (Meinhardt, 1982; Murray and Oster, 1984). Among them, one of the most plausible in biological systems is the reaction-diffusion (RD) mechanism which was first presented by A. Turing in 1952 (Gierer and Meinhardt, 1972; Turing, 1952), and mathematically refined by mathematical biologists (Meinhardt and Gierer, 2000a; Murray, 2003). In the model, the spatial pattern is made as stationary waves generated by the interactive RD of putative chemical substances. According to mathematical modelling using computer simulation, an RD system is able to generate stable and evenly-spaced patterns when the whole network satisfies a condition of "local activation and long range inhibition."(Meinhardt and Gierer, 2000a) The spatial patterns made by the system (e.g.,"RD pattern" or "Turing pattern") do not need any prepattern, and autonomously regenerate when artificially disturbed. In the 1970s, extensive computational studies showed that the $\mathrm{RD}$ model can reproduce a variety of morphogenetic phenomena of animal development, those that the pre-pattern model cannot explain. (Meinhardt, 2003; Murray, 2003)

However, in spite of its theoretical importance, until very recently, Turing's theory was not widely accepted by experimental biologists for two major reasons. First, the main concept of the theory, namely that the pattern is made by a wave, is quite unfamiliar to many experimental biologists. Second, it is difficult to prove the existence of such a wave by some experiment. In order to prove that the RD mechanism functions in a particular morphogenetic event, we need to show that the pattern possesses the dynamic nature of the RD wave.

\section{Morphological phenomena in which the involvement of the RD mechanism is suspected}

For about 40 years after Turing's original work, studies of RD mechanisms were almost exclusively theoretical, and there was little convincing experimental evidence for Turing patterns in any system, biological or otherwise. The first clear experimental support for this mechanism came in chemical experiments in the early 1990s. Castets et.al. and Ouyang et. al. succeeded in making the Turing pattern using complex chemical reactions. (Castets et al., 1990; Ouyang and Swinney, 1991) These works encouraged biologists to study the theoretical mechansim, and Kondo and Asai found that the pigmentation pattern on the skin of an angel fish moved exactly in the manner that Turing's theory predicted (Kondo and Asai, 1995).

They recorded the pattern change of the pigment pattern of a marine angelfish, Pomacanthus imperator, and suggested that the time course of the pattern change is identical to that predicted by Turing's theory. The involvement of the Turing mechanism is now seriously investigated experimentally in several morphological events; hair pattern of mammals (Jung et al., 1998; Nagorcka, 1983; Sick et al., 2006), feather patterns of birds (Harris et al., 2005; Jiang et al., 2004; Prum and Williamson, 2002), regeneration of hydra (Bode, 2003; Gierer et al., 1972; Technau et al.,
A
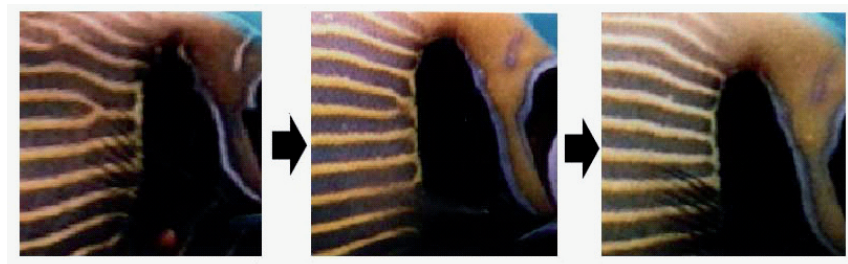

B
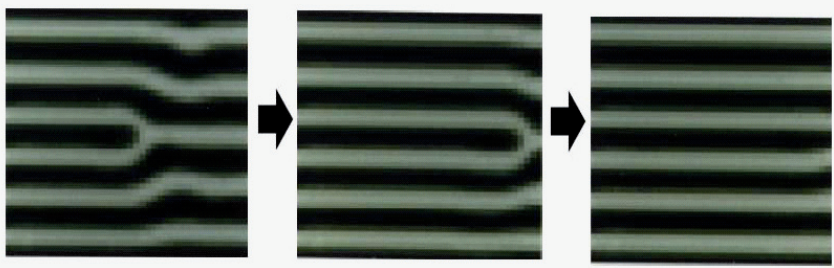

C
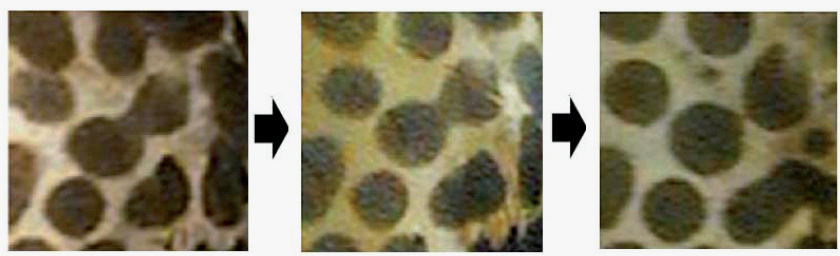

D
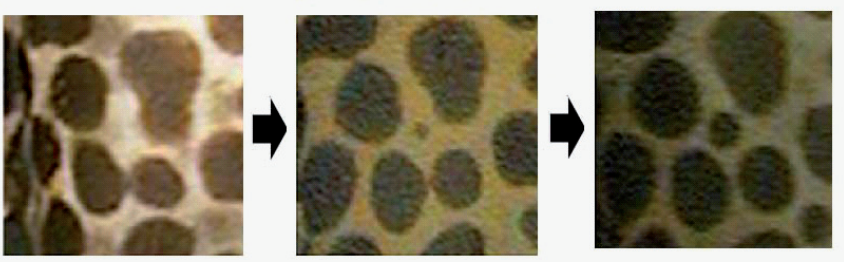

E
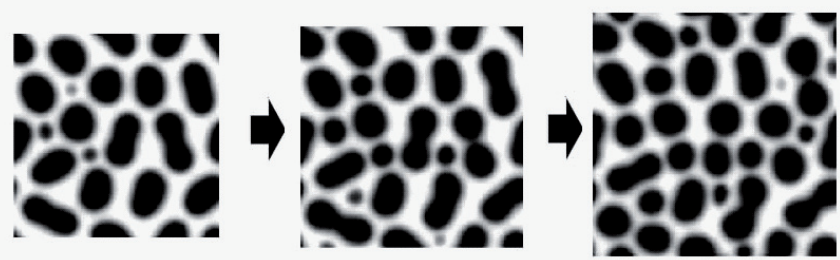

Fig. 1. Dynamic pattern change in the fish and simulation. (A) Change of stripe pattern in the skin of Pomacanthus imperator during 90 days and (B) the prediction made by simulation of a reaction diffusion mechanism. Sliding of the branch point is observed in both systems. Change of spot pattern occurring in the skin of a catfish, Plecostoms sp., during 14 days $(\mathbf{C}, \mathbf{D})$ and the simulation (E). Division (C) and insertion (D) of the spot are observed in both real fish and in the simulation based on the RD model. From (Kondo and Asai, 1995) and (Asai et al., 1999).

2000) and right-left determination in the vertebrates (Hamada et al., 2001; Hamada et al., 2002; Nakamura et al., 2006). In these cases, candidates for the core functional molecules of pattern formation were proposed.

For example, in the case of the mouse hair pattern, Sick et. al. suggested that the WNT and DKK proteins play the role of the putative activator and inhibitor in the reaction-diffusion system (Sick et al., 2006). Moreover, by artificially changing the parameters of the interactions, it is possible to induce the pattern change that is predicted from the simulation, suggesting that an RD mechanism underlies the determination of the hair distribution (Sick et al., 2006). However, most of these morphogenetic events are irreversible, and the patterns that we can observe are completed and fixed ones. Therefore, it is usually impossible to directly detect the existence of the "wave" in the course of the 
pattern-forming event.

\section{Characteristic movement of the RD wave is visible in the animal skin}

To date, pigmentation patterns in animal skins (Murray et al., 1990; Murray and Oster, 1984), feathers of birds (Harris et al., 2005; Prum and Williamson, 2002), and shells of the snails (Meinhardt, 2003) are the only examples in which we can detect the dynamic nature of Turing waves as a time course of the pattern change. Especially, the 2D skin pattern of the fish is quite convenient to study because waves are sometimes active even when the fish has reached adulthood.

For example, when a striped angel fish (Pomacanthus imperator) grows, the branching points of the stripes slide horizontally as the zip opens, and add a number of stripes; eventually the spacing between the stripes remains stable (Fig. 1A) (Kondo and Asai, 1995). In the case of spotted catfish (Plecostoms sp.), both division of the spots and insertion of the new spots occur to retain the density and size of the spots (Fig. 1B) (Asai et al., 1999). Both stripes and the spots are the most typical 2D patterns generated by the RD mechanism, and the time course of the pattern change possesses the characteristics of the dynamics of RD waves, strongly suggesting that the RD mechanism underlies the process of pigment-pattern formation of fish.

\section{Zebrafish as a model system for studying patterning mechanisms}

In order to understand the principles of autonomous pattern formation controlled by the dynamic mechanism, it is important to identify the molecular-level network that functions in skin pattern formation of fish where the wave is active. Observation on the dynamics of the molecules related to the RD pattern formation would dramatically contribute to our understanding of how animals keep the stable structure under an environment that is full of disturbances. Fortunately, zebrafish, a small fish species with very clear stripes in their trunk and fins, was selected as a model animalÄfor biological studies, and for the use of the genomic information and molecular-genetic technologies that are available to identify the molecular mechanism of pigment-pattern formation.

\section{The pigment pattern of zebrafish retains the dynamic nature of the RD wave during the post embryonic stage}

The pattern of skin pigmentation in zebrafish is composed of three types of pigment cells distributed in the hypodermis: melanophores, the main component of dark stripes; xanthophores, the main component of light stripes; and iridophores (Hirata et al., 2003; Kelsh, 2004). Although different from the stripes of Pomacanthus imperator, the stripes of zebrafish do not become rearranged during normal growth, artificial disturbance of the pattern can induce the characteristic pattern change that is specific to the RD mechanism. Kirschbaum (Kirschbaum, 1975a) cut a piece of skin from the trunk and re-planted it at an angle to its original orientation. The stripes on the graft were terminated at the edge of the transplant when the operation was completed. But, he observed that the ends of the stripes moved and rejoined the end of the stripes of the host skin. Parichy and Turner (Parichy and Turner, 2003) used a temperature sensitive mutant of panther(c-fms)gene, that is required to maintain both xanthophores and melanophores, to erase the pattern and observe the regeneration of the pigment pattern. They found that when the pigment cells were in the tail fins were'killed, development of pigment cells occurred to fill the vacant space, but the regenerated stripes often lost the original directionality. These experiments suggest that the stripes of the zebrafish stripes have the ability to repair themselves. and that the process is independent of the pre-pattern.

By using laser light to kill the pigment cells, it is possible to induce more dynamic movement of the stripes that is characteristic of the stationary wave of the RD mechanism. Yamaguchi et al. (Yamaguchi et al., 2007) continuously killed the melanophores in the dorsal two black stripes of the young (40 to 80 day) and observed that the ventral black stripe bent and moved dorsally to fill the vacant space. (Fig. 2) This movement of the stripes strongly suggests that the pigment pattern of the zebrafish is made and maintained dynamically by the $\mathrm{RD}$, or by a very similar mechanism.
A

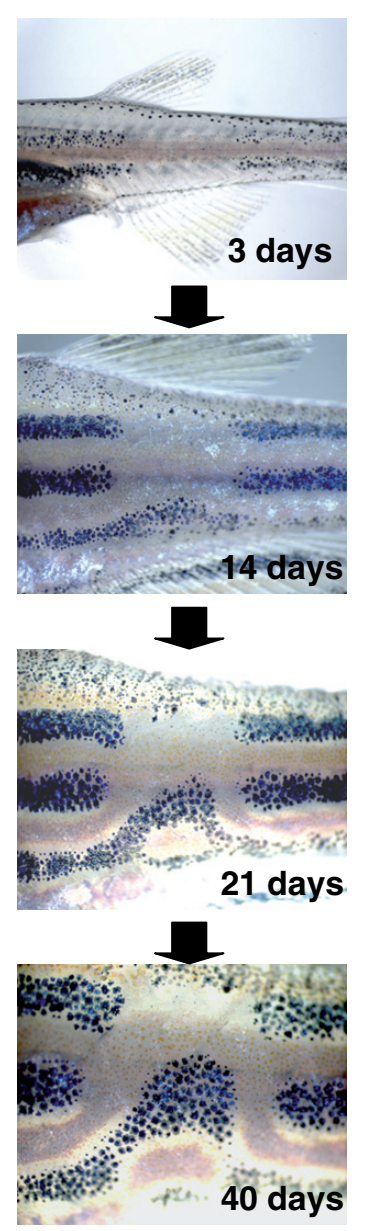

B

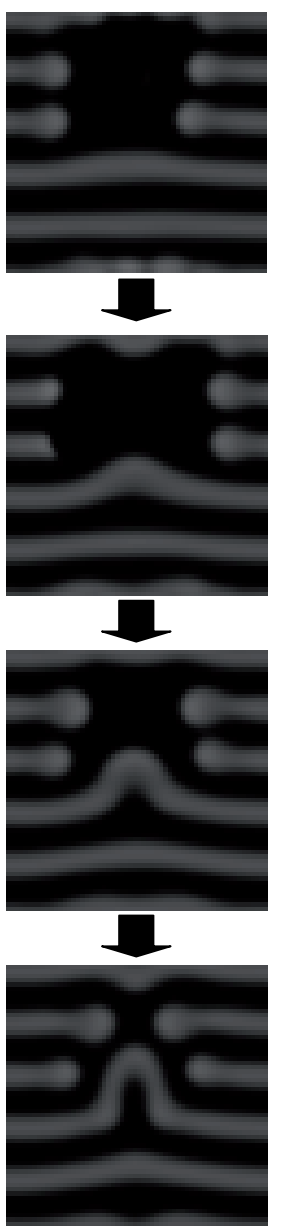

Fig. 2.Dynamic change of the zebrafish pigment pattern induced by laser experiment. (A) Time course of the pattern change. Melanophores in upper two black stripes are killed by laser light. (B) Time-lapse captured images of the regeneration process produced by simulation of reactiondiffusion mechanisms. From Yamaguchi et al. (2007). 


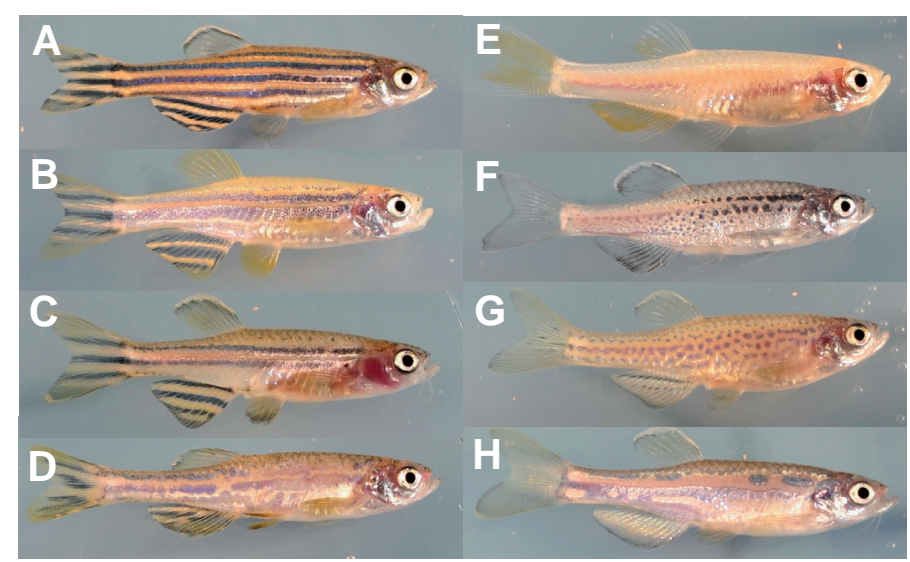

Fig. 3. Pigment patterns in zebrafish mutants. (A) Wildtype; (B) sparse; (C) nacre; (D) puma; (E) panther; (F) jaguar (obelix) and (G) leopard.

Another important suggestion which arises from these experiments is that the pigment cells do not simply make the hidden pattern visible, but are the major players in the pattern formation. Therefore, to uncover the mechanism, the most critical step should be the identification of the interactions between the two types of pigment cells (melanophores and xanthophores).

\section{Mutants that affect both development of pigment cells and the resulting pattern}

Several mutants that affect the skin pigment pattern have been isolated from large-scale screening ethylnitrosourea (enu) chemical mutagenesis and the selection of spontaneous mutations (Haffter et al., 1996; Kelsh et al., 1996; Odenthal et al., 1996). Illustrations and summaries of the experimental data from these mutants are shown in Table 1 and Fig. 3. By gene cloning and functional analysis using a series of elegant chimera experiments, their functions in the pigment cell development is gradually becoming clear.

These mutants are classified into two categories: those with a defect in the development of pigment cells; and those with normal development of pigment cells at the embryonic stage, but with a disrupted pattern in the adult fish. Molecular genetic studies of the mutants in the first category have shown that nacre (Lister et al., 1999), sparse (Parichy et al., 1999), and rose (Parichy et al., 2000a) are required for the development of melanophores, and that panther (Parichy et al., 2000b) is required for the develop- ment of xanthophores. The nacre gene codes a transcription factor Mitf1 that is required by the cells to develop into melanophore precursor. Sparse and panthercode the class II receptor tyrosine kinases, $c$-kit and $c$-fms, respectively. rose codes the endothelin receptor b1. sparse fish lack embryonic melanophores, but the adult melanophores are normally integrated in the stripes. The number of embryonic melanophores in rose fish is normal, but a reduced number of adult melanophores compose the disturbed stripe (Johnson et al., 1995b). The double mutant of these genes loses almost all the melanophores, suggesting that there are two different populations in the melanophores, and only the adult type is required for the stripe pattern formation (Johnson et al., 1995b).

Interestingly, when one of the pigment cell type failed to develop, other type of pigment cells fail to localize to their normal positions (Johnson et al., 1995a; Lister etal., 1999; Parichy etal., 2000a; Parichy et al., 2000b; Parichy et al., 1999; Rawls et al., 2001). nacre fish lack all melanophores and panther fish lack xanthophores. In both cases, the remaining pigment cells cannot form clear stripes but disperse randomly or form aggregates of uncertain shape. However, when a pigment cell type that is lost in the mutant is introduced, clear stripes are regenerated only in the region where both types of pigment cells exist. These experimental results show that mutual interaction between melanophores and xanthophores plays a critical role in the generation of skin pigmentation pattern (Kelsh, 2004; Maderspacher and NussleinVolhard, 2003; Parichy and Turner, 2003; Parichy et al., 2003).

\section{Mutants that affect the pigment pattern, but not the development of pigment cells}

Mutants of jaguant obelix(Maderspacher and Nusslein-Volhard, 2003) and leopard (Kirschbaum, 1975b; Maderspacher and Nusslein-Volhard, 2003) belong to this second category. In these mutants, development and distribution of the pigment cells is normal in embryos and young fish ( 4weeks). In adult fish, although development of pigment cells is normal, their spatial arrangement (pattern) is changed, suggesting that these genes are specifically required for pattern formation. The jaguarmutant fish have wider stripes and the leopardfish have spotted patterns. Maderspacher et al. performed a series of chimera experiments with the mutants, and deduced the role of each gene in the pattern forming mechanism as follows. Jaguar/obelx is required in melanophores to promote their aggregation and to control boundary integuity. The leopardgene regulates homotypic interaction within both melanophores and xanthophores. Further, both are required

TABLE 1

\section{SELECTED GENES INVOLVED IN PIGMENT PATTERN FORMATION IN FISH}

\begin{tabular}{|c|c|c|c|c|c|}
\hline Mutant & Gene & Pattern & Melanophore & Xanthophore & iridophore \\
\hline sparse & kit /receptor tyrosine kinase & Stripe, boundary is slightly ambiguous & EM absent Present & Present & Present \\
\hline rose & ednrb1/G-protein coupled receptor & Fewer stripes, but normal in fins & LM absent & Present & Absent \\
\hline puma & not cloned & Purely formed & LM absent & Present & Present \\
\hline nacre & mitf1/transcription factor & Clusters of xanthophores, but purely striped & Absent & Present & Present \\
\hline panther & fms /receptor tyrosine kinase & Scatterd melanophores & Fewer & Absent & Present \\
\hline jaguar(obelix) & kir7.1/potassium chnnel & Wider stripes & Present & Present & Present \\
\hline leopard & connexin41.8/ gap junction & Spots & Present & Present & Present \\
\hline
\end{tabular}


to control the boundary shape (Maderspacher and NussleinVolhard, 2003). The positional cloning of the jaguar mutant revealed that this gene codes a inwardly rectifying potassium channel, Kir7.1 (Iwashita et al., 2006). Kir channels are a group of ion channels which transfer potassium ions unidirectionally from outside to inside the cell (Doring et al., 1998; Kim et al., 2000; Kusaka et al., 2001; Nakamura et al., 2000; Shimura et al., 2001). It is known from the study of cultured cells that this class of channels is responsible for the stability of membrane potential and sensitivity to the external signals (Suzuki et al., 2003; Wischmeyer et al., 2000; Yasuda et al., 2003). Recently Jantzi et al. reported that the kir channel (Kir2.2) facilitates cell-to-cell communication that propagates the contraction signal in hamster retractor muscle feed artery (Jantzi et al., 2006). In zebrafish, the Kir7.1 gene is expressed in melanophores (Iwashita et al., 2006), suggesting that the channel controls the interaction of the melanophores. The gene responsible for the leopardmutant is cloned and identified to be a component of gap junctions, connexin41.8 (Watanabe et al., 2006). Connexin41.8 is expressed in many kinds of skin cells including melanophores and xanthophores. As the expression level of the connexin41.8gene is very low in cells of the zebrafish skin, little is known about the function and role of the molecule in pigment-pattern formation. However, Johnson et al. reported recently that another class of gap junction gene, connexin43, encodes the shortfin (sof) gene, which controls the length of the fins of the zebrafish (lovine et al., 2005). This fact is quite interesting because it implies that a similar mechanism could control the size of limbs and the 2D patterns in the skin.

\section{Future directions}

Although molecular genetic studies have identified genes and molecules involved in pigment-pattern formation in fish, the questions as to how they are organized and how they generate the RD wave, remain largely unknown. To understand pigment-pattern formation, it is necessary to integrate all the molecular reactions and deduce how such complex systems behave. For this purpose, the framework of RD mechanism is useful. In most of the mathematical models of the RD systems, the putative molecular network is composed of chemicals that control the synthesis of molecules and their diffusion in the field. However, it is also possible to compose an equivalent network with the interaction of two types of cell (melanophores and xanthophores). Therefore there is no theoretical difficulty in applying the model to zebrafish pigment-pattern formation.

Mathematical studies on RD and related autonomous patternforming systems, revealed that the necessary conditions for the formation of a spatial pattern (spots and stripes) is the combination of "local activation" and "long range inhibition" (Meinhardt and Gierer, 2000b). Recentry, Nakamasu estimated the in vivo interactions between the pigment cells by observing regeneration in the area where the pigment cells in the surrounded region were killed by laser (Nakamasu et al., 2009). They found that the effect of xanthophores on the melanophore is different depending on the distance of the cells, and the deduced cell-cell interaction network is consistent with the "local activation and long range inhibition" rule. Temporally, we have little experimental data which connects molecular data to the macroscopic observations which suggest the involvement of the Turing mechanism in pigment pattern formation. Use of advanced live-imaging techniques will help to assess whether or not the functioning molecules behave as the model predicts, and will also help to identify the molecular-level network. With the cooperation of advanced molecular genetics and mathematical modeling, the long unsettled question of how animal skin patterns are generated will be solved in the near future.

\section{References}

AGATA, K., SAITO, Y. AND NAKAJIMA, E. (2007). Unifying principles of regeneration I: Epimorphosis versus morphallaxis. Dev Growth Differ 49: 73-78.

ASAI, R., TAGUCHI, E., KUME, Y., SAITO, M. AND KONDO, S. (1999). Zebrafish leopard gene as a component of the putative reaction-diffusion system. Mechanisms of Development 89: 87-92.

BEST, J. B. AND MORITA, M. (1982). Planarians as a model system for in vitro teratogenesis studies. Teratog Carcinog Mutagen 2: 277-291.

BODE, H. R. (2003). Head regeneration in Hydra. Dev Dyn 226: 225-236.

CASTETS, V., DULOS, E., BOISSONADE, J. AND DE KEPPER, P. (1990). Experimental Evidence of a Sustained Standing Turing-Type Nonequilibrium Chemical Pattern. Phys. Rev. Lett 64: 2953-2956.

DORING, F., DERST, C., WISCHMEYER, E., KARSCHIN, C. SCHNEGGENBURGER, R., DAUT, J. AND KARSCHIN, A. (1998). The epithelial inward rectifier channel Kir7.1 displays unusual $\mathrm{K}+$ permeation properties. JNeurosci18: 8625-8636.

GIERER, A., BERKING, S., BODE, H., DAVID, C. N., FLICK, K., HANSMANN, G., SCHALLER, H. AND TRENKNER, E. (1972). Regeneration of hydra from reaggregated cells. Nat New Bio/239: 98-101.

GIERER, A. AND MEINHARDT, H. (1972). A theory of biological pattern formation. Kybernetik 12: 30-39.

GILBERT, S. (2003). Developmental biology. Sunderland(Massachusetts): Sinauer Associates.

GUDER, C., PHILIPP, I., LENGFELD, T., WATANABE, H., HOBMAYER, B. AND HOLSTEIN, T. W. (2006). The Wnt code: cnidarians signal the way. Oncogene 25: 7450-7460.

HAFFTER, P., GRANATO, M., BRAND, M., MULLINS, M. C., HAMMERSCHMIDT, M., KANE, D. A., ODENTHAL, J., VANEEDEN, F. J., JIANG, Y. J., HEISENBERG, C. P. ET AL. (1996). The identification of genes with unique and essential functions in the development of the zebrafish, Danio rerio. Development 123: 1 36.

HAMADA, H., MENO, C., SAIJOH, Y., ADACHI, H., YASHIRO, K., SAKUMA, R. AND SHIRATORI, H. (2001). Role of asymmetric signals in left-right patterning in the mouse. Am J Med Genet 101: 324-327.

HAMADA, H., MENO, C., WATANABE, D. AND SAIJOH, Y. (2002). Establishment of vertebrate left-right asymmetry. Nat Rev Genet 3: 103-113.

HARRIS, M. P., WILLIAMSON, S., FALLON, J. F., MEINHARDT, H. AND PRUM, R. O. (2005). Molecular evidence for an activator-inhibitor mechanism in development of embryonic feather branching. Proc Natl Acad Sci USA 102: 11734-11739.

HIRATA, M., NAKAMURA, K., KANEMARU, T., SHIBATA, Y. AND KONDO, S. (2003). Pigment cell organization in the hypodermis of zebrafish. Dev Dyn227: 497-503.

IOVINE, M. K., HIGGINS, E. P., HINDES, A., COBLITZ, B. AND JOHNSON, S. L. (2005). Mutations in connexin43 (GJA1) perturb bone growth in zebrafish fins. Dev Bio/278: 208-219.

IWASHITA, M., WATANABE, M., ISHII, M., CHEN, T., JOHNSON, S. L., KURACHI, Y., OKADA, N. AND KONDO, S. (2006). Pigment pattern in jaguar/obelix zebrafish is caused by a Kir7.1 mutation: implications for the regulation of melanosome movement. PLoS Genet 2: e197.

JANTZI, M. C., BRETT, S. E., JACKSON, W. F., CORTELING, R., VIGMOND, E. J. AND WELSH, D. G. (2006). Inward rectifying potassium channels facilitate cell-to-cell communication in hamster retractor muscle feed arteries. $A m J$ Physiol Heart Circ Physiol 291: H1319-H1328.

JIANG, T. X., WIDELITZ, R. B., SHEN, W. M., WILL, P., WU, D. Y., LIN, C. M., 
JUNG, H. S. AND CHUONG, C. M. (2004). Integument pattern formation involves genetic and epigenetic controls: feather arrays simulated by digital hormone models. Int J Dev Biol 48: 117-135.

JOHNSON, S. L., AFRICA, D., HORNE, S. AND POSTLETHWAIT, J. H. (1995a). Half-tetrad analysis in zebrafish: mapping the ros mutation and the centromere of linkage group I. Genetics 139: 1727-1735.

JOHNSON, S. L., AFRICA, D., WALKER, C. AND WESTON, J. A. (1995b). Genetic control of adult pigment stripe development in zebrafish. Dev Bio/167: 27-33.

JUNG, H. S., FRANCIS-WEST, P. H., WIDELITZ, R. B., JIANG, T. X., TINGBERRETH, S., TICKLE, C., WOLPERT, L. AND CHUONG, C. M. (1998). Local inhibitory action of BMPs and their relationships with activators in feather formation: implications for periodic patterning. Dev Bio/196: 11-23.

KELSH, R. N. (2004). Genetics and evolution of pigment patterns in fish. Pigment Cell Res 17: 326-336.

KELSH, R. N., BRAND, M., JIANG, Y. J., HEISENBERG, C. P., LIN, S., HAFFTER, P., ODENTHAL, J., MULLINS, M. C., VAN EEDEN, F. J., FURUTANI-SEIKI, M. ET AL. (1996). Zebrafish pigmentation mutations and the processes of neural crest development. Development 123: 369-389.

KIM, S. J., KERST, G., SCHREIBER, R., PAVENSTADT, H., GREGER, R., HUG, M. J. AND BLEICH, M. (2000). Inwardly rectifying K+ channels in the basolateral membrane of rat pancreatic acini. Pflugers Arch 441: 331-340.

KIRSCHBAUM, F. (1975a). Untersuchnugen uber das Farbmuster der Zebrabarbe Brachydanio rerio. Roux's Arch. Dev. Biol. 177: 129-152.

KIRSCHBAUM, F. (1975b). Untersuchungen ueber das Farbmuster der Zebrabarbe Brachydanio rerio (Cyprinidae, Teleostei). Wilhelm Roux's Arch 177: 129-152.

KONDO, S. AND ASAI, R. (1995). A reaction-diffusion wave on the skin of the marine angelfish Pomacanthus. Nature 376: 765-768.

KUSAKA, S., INANOBE, A., FUJITA, A., MAKINO, Y., TANEMOTO, M., MATSUSHITA, K., TANO, Y. AND KURACHI, Y. (2001). Functional Kir7.1 channels localized at the root of apical processes in rat retinal pigment epithelium. J Physiol 531: 27-36.

LISTER, J. A., ROBERTSON, C. P., LEPAGE, T., JOHNSON, S. L. AND RAIBLE, D. W. (1999). nacre encodes a zebrafish microphthalmia-related protein that regulates neural-crest-derived pigment cell fate. Development126:3757-3767.

MADERSPACHER, F. AND NUSSLEIN-VOLHARD, C. (2003). Formation of the adult pigment pattern in zebrafish requires leopard and obelix dependent cell interactions. Development 130: 3447-3457.

MEINHARDT, H. (1982). Models of biological pattern formation. Academic press, London.

MEINHARDT, H. (2003). The Algorithmic Beauty of Sea Shells. Springer, Berlin.

MEINHARDT, H. AND GIERER, A. (2000a). Pattern formation by local selfactivation and lateral inhibition. Bioessays 22: 753-760.

MEINHARDT, H. AND GIERER, A. (2000b). Pattern formation by local selfactivation and lateral inhibition.[see comment]. Bioessays 22: 753-760.

MURRAY, J. (2003). Mathematical Blology. Springer, Berlin.

MURRAY, J. D., DEEMING, D. C. AND FERGUSON, M. W. (1990). Size-dependent pigmentation-pattern formation in embryos of Alligator mississippiensis: time of initiation of pattern generation mechanism. Proc $R$ Soc Lond B Biol Sci 239: 279-293.

MURRAY, J. D. AND OSTER, G. F. (1984). Generation of biological pattern and form. IMA J Math App/ Med Biol1: 51-75.

NAGORCKA, B. N. (1983). Evidence for a reaction-diffusion system as a mechanism controlling mammalian hair growth. Biosystems 16: 323-332.

NAKAMASU, A., TAKAHASHI, G., KANBE, A. and KONDO, S. (2009) Interactions between the zebrafish pigment cells responsible for the generation of Turing pattern. Proc. Natl. Acad. Sci. USA 106: 8429-8434.

NAKAMURA, N., SUZUKI, Y., IKEDA, Y., NOTOYA, M. AND HIROSE, S. (2000). Complex structure and regulation of expression of the rat gene for inward rectifier potassium channel Kir7.1. J Biol Chem 275: 28276-28284.

NAKAMURA, T., MINE, N., NAKAGUCHI, E., MOCHIZUKI, A., YAMAMOTO, M., YASHIRO, K., MENO, C. AND HAMADA, H. (2006). Generation of robust leftright asymmetry in the mouse embryo requires a self-enhancement and lateralinhibition system. Dev Cel/11: 495-504.

ODENTHAL, J., ROSSNAGEL, K., HAFFTER, P., KELSH, R. N., VOGELSANG, E.,
BRAND, M., VAN EEDEN, F. J., FURUTANI-SEIKI, M., GRANATO, M., HAMMERSCHMIDT, M. ET AL. (1996). Mutations affecting xanthophore pigmentation in the zebrafish, Danio rerio. Development 123: 391-398.

OUYANG, Q. AND SWINNEY, H. (1991). Transition from a uniform state to hexagonal and striped Turing patterns. Nature 352: 610-612.

PARICHY, D. M., MELLGREN, E. M., RAWLS, J. F., LOPES, S. S., KELSH, R. N AND JOHNSON, S. L. (2000a). Mutational analysis of endothelin receptor b1 (rose) during neural crest and pigment pattern development in the zebrafish Danio rerio. Dev. Biol. 227: 294-306.

PARICHY, D. M., RANSOM, D. G., PAW, B., ZON, L. I. AND JOHNSON, S. L. (2000b). An orthologue of the kit-related gene fms is required for development of neural crest-derived xanthophores and a subpopulation of adult melanocytes in the zebrafish, Danio rerio. Development 127: 3031-3044.

PARICHY, D. M., RAWLS, J. F., PRATT, S. J., WHITFIELD, T. T. AND JOHNSON, S. L. (1999). Zebrafish sparse corresponds to an orthologue of c-kit and is required for the morphogenesis of a subpopulation of melanocytes, but is not essential for hematopoiesis or primordial germ cell development. Development 126: 3425-3436

PARICHY, D. M. AND TURNER, J. M. (2003). Temporal and cellular requirements for Fms signaling during zebrafish adult pigment pattern development. Deve/opment 130: 817-833.

PARICHY, D. M., TURNER, J. M. AND PARKER, N. B. (2003). Essential role for puma in development of postembryonic neural crest-derived cell lineages in zebrafish. Dev Biol 256: 221-241.

PRUM, R. O. AND WILLIAMSON, S. (2002). Reaction-diffusion models of withinfeather pigmentation patterning. Proc Biol Sci269: 781-792.

RAWLS, J., EM., M. AND SL., J. (2001). How the zebrafish gets its stripes. Dev Bio/ 240: 301-314.

SHIMURA, M., YUAN, Y., CHANG, J. T., ZHANG, S., CAMPOCHIARO, P. A. ZACK, D. J. AND HUGHES, B. A. (2001). Expression and permeation properties of the $\mathrm{K}(+)$ channel Kir7.1 in the retinal pigment epithelium. JPhysio/ 531: 329 346.

SICK, S., REINKER, S., TIMMER, J. AND SCHLAKE, T. (2006). WNT and DKK determine hair follicle spacing through a reaction-diffusion mechanism. Science 314: $1447-1450$

SUZUKI, Y., YASUOKA, Y., SHIMOHAMA, T., NISHIKITANI, M., NAKAMURA, N., HIROSE, S. AND KAWAHARA, K. (2003). Expression of the K+ channel Kir7.1 in the developing rat kidney: role in $\mathrm{K}+$ excretion. Kidney Int 63: 969-975.

TECHNAU, U., CRAMER VON LAUE, C., RENTZSCH, F., LUFT, S., HOBMAYER, B., BODE, H. R. AND HOLSTEIN, T. W. (2000). Parameters of self-organization in Hydra aggregates. Proc Nat/ Acad Sci USA 97: 12127-12131.

TURING, A. (1952). The chemical basis of morphogenesis. Philos Trans $R$ SoC Lond $B$ 237: 37-72.

WATANABE, M., IWASHITA, M., ISHII, M., KURACHI, Y., KAWAKAMI, A., KONDO, S. AND OKADA, N. (2006). Spot pattern of leopard Danio is caused by mutation in the zebrafish connexin41.8 gene. EMBO Reports 7: 893-897.

WISCHMEYER, E., DORING, F. AND KARSCHIN, A. (2000). Stable cation coordination at a single outer pore residue defines permeation properties in Kir channels. FEBS Lett 466: 115-120.

WOLPERT, L. (1969). Positional information and the spatial pattern of cellular differentiation. J Theor Biol 25: 1-47.

WOLPERT, L. (1989). Positional information revisited. Development 107 SUPPL 3-12.

WOLPERT, L. (2006). Principles of Development. Oxford University Press, New York.

WOLPERT, L., HICKLIN, J. AND HORNBRUCH, A. (1971). Positional information and pattern regulation in regeneration of hydra. Symp Soc Exp Bio/25: 391-415

YAMAGUCHI, M., YOSHIMOTO, E. AND KONDO, S. (2007). Pattern regulation in the stripe of zebrafish suggests an underlying dynamic and autonomous mechanism. Proc Natl Acad Sci USA 104: 4790-4793.

YASUDA, K., SHIMURA, M., NAKAZAWA, T., SATO, H., TOMITA, H., SUGANO, E. AND TAMAI, M. (2003). Expression and functional properties of unique inward rectifier $\mathrm{K}_{+}$channel Kir7.1 in the porcine iris and retinal pigment epithelium. Curr Eye Res 27: 279-287. 


\section{Further Related Reading, published previously in the Int. J. Dev. Biol.}

See our Special Issue Developmental Morphodynamics edited by Lev Beloussov and Richard Gordon at: http://www.ijdb.ehu.es/web/contents.php?vol=50\&issue=2-3

See our Special Issue Fertilization, in honor of David L. Garbers and edited by Paul M. Wassarman and Victor D. Vacquier at: http://www.ijdb.ehu.es/web/contents.php?vol=52\&issue=5-6

Analyses of regenerative wave patterns in adult hair follicle populations reveal macro-environmental regulation of stem cell activity Maksim V. Plikus, Randall B. Widelitz, Rob Maxson and Cheng-Ming Chuong

Int. J. Dev. Biol. in press

Expression of the novel gene Ened during mouse and Xenopus embryonic development Renata Meszaros, Ina Strate, Edgar M. Pera and Madeleine Durbeej

Int. J. Dev. Biol. (2008) 52: 1119-1122

Drosophila retinal pigment cell death is regulated in a position-dependent manner by a cell memory gene

Nicolas Dos-Santos, Thomas Rubin, Fabienne Chalvet, Pierre Gandille, Frederic Cremazy, Jacqueline Leroy, E. Boissonneau and Laurent Théodore

Int. J. Dev. Biol. (2008) 52: 21-31

Pax7 identifies neural crest, chromatophore lineages and pigment stem cells during zebrafish development

Ana M Lacosta, Jesús Canudas, Cristina González, Pedro Muniesa, Manuel Sarasa and Luis Domínguez

Int. J. Dev. Biol. (2007) 51: 327-331

Before programs: The physical origination of multicellular forms

Stuart A. Newman, Gabor Forgacs and Gerd B. Müller

Int. J. Dev. Biol. (2006) 50: 289-299

The dynamic geometry of mass cell movements in animal morphogenesis

Vladimir G. Cherdantsev

Int. J. Dev. Biol. (2006) 50: 169-182

From observations to paradigms; the importance of theories and models. An interview with Hans Meinhardt

Richard Gordon and Lev Beloussov

Int. J. Dev. Biol. (2006) 50: 103-111

Involvement of Hex in the initiation of feather morphogenesis

Akiko Obinata and Yoshihiro Akimoto

Int. J. Dev. Biol. (2005) 49: 953-960

Expression of Hex during feather bud development

Akiko Obinata and Yoshihiro Akimoto

Int. J. Dev. Biol. (2005) 49: 885-890

Integument pattern formation involves genetic and epigenetic controls: feather arrays simulated by digital hormone models.

Ting-Xin Jiang, Randall B Widelitz, Wei-Min Shen, Peter Will, Da-Yu Wu, Chih-Min Lin, HanSung Jung and Cheng-Ming Chuong

Int. J. Dev. Biol. (2004) 48: 117-135

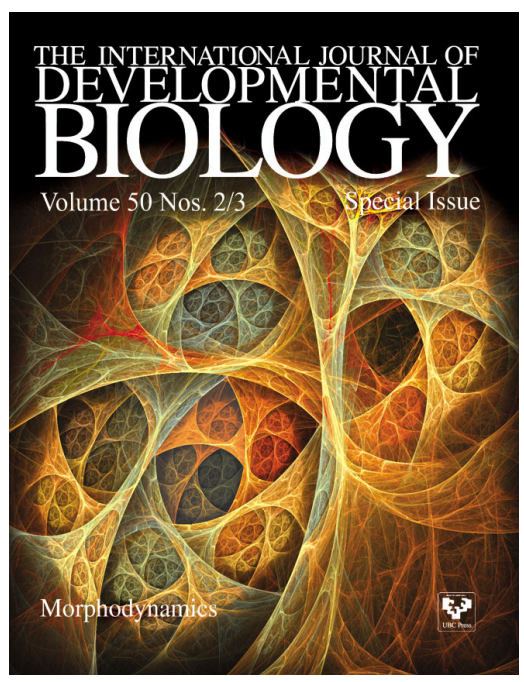

5 yr ISI Impact Factor $(2008)=3.271$

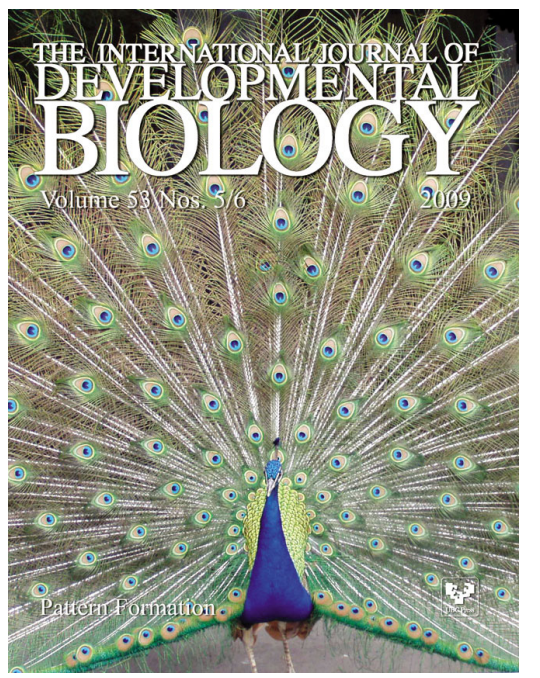

